JPDN ISSN 2579-6461 (Online) ISSN 2460-6324 (Print)

Jurnal Pendidikan Dasar Nusantara

Volume 5 | Nomor 2 | Januari 2020|

DOI: https://doi.org/10.29407/jpdn.v5i2.13999

\title{
PENGEMBANGAN PEDOMAN E-MODUL BERORIENTASI STUDENT ACTIVE LEARNING SEBAGAI PENDUKUNG PEMBELAJARAN DI SEKOLAH DASAR
}

\author{
Kuncahyono ${ }^{1}$, Dian Fitri Nur Aini ${ }^{2}$ \\ kuncahyono@umm.ac.id ${ }^{1}$, dianfitri@umm.ac.id ${ }^{2}$ \\ PGSD, FKIP, Universitas Muhammadiyah Malang ${ }^{1}$ \\ PGSD, FKIP, Universitas Muhammadiyah Malang ${ }^{2}$ \\ No Handphone : $+6285645844298^{1},+6282233663566^{2}$
}

\begin{abstract}
Abstrak: Penelitian ini bertujuan untuk (1) menghasilkan pedoman e-modul berorientasi student active learning di Sekolah Dasar yang valid; (2) menghasilkan kelayakan pedoman e-modul berorientasi student active learning di Sekolah Dasar, dan (3) menghasilkan pedoman e-modul berorientasi student active learning yang praktis. Penelitian ini menggunakan desain penelitian pengembangan model ADDIE yang terdiri dari 5 tahapan yaitu analisis, perancangan, pengembangan, penerapan, dan evaluasi. Hasil penelitian menunjukkan bahwa hasil uji coba validasi ahli bahan ajar dan ahli materi maka rata-rata skor yang diperoleh yaitu 83,95 dengan kriteria valid. Hasil uji coba pengguna (guru dan siswa) maka rata-rata skor yang diperoleh yaitu 3,5 dengan sangat baik/sangat praktis.
\end{abstract}

Kata Kunci: Pedoman e-modul, Pembelajaran Tematik, Student Active learning

\section{DEVELOPMENT OF E-MODULE GUIDELINES ORIENTED TOWARDS ACTIVE STUDENT LEARNING AS A SUPPORTER OF LEARNING IN ELEMENTARY SCHOOL}

\begin{abstract}
This study aims to (1) produce valid e-module guidelines for active student learning in elementary schools that are valid; (2) produce eligibility guidelines for student active learning-oriented e-modules in Elementary Schools, and (3) produce practical student learning oriented e-module guidelines. This research uses the ADDIE model development research design which consists of 5 levels, namely analysis, design, development, application, and evaluation. The results showed that the results of the validation trial of teaching materials experts and material experts, the average score obtained was 83.95 with valid criteria. The results of user trials (teachers and students) then the average score obtained is 3.5 very well / very practical.
\end{abstract}

Keywords: e-module guide, Thematic Learning, Student Active learning 
Kuncahyono, Dian. Pengembangan Pedoman E-Modul Berorientasi

PENDAHULUAN

Pencapaian pembelajaran ditandai dengan tersampaikannya tujuan pembelajaran yang sudah direncanakan dalam RPP. Tujuan pembelajaran yang sudah disusun dengan baik tidak akan berhasil tanpa adanya transformasi antara guru dan siswa. Senada dengan Mulyasa (2007), guru seharusnya memiliki kompetensi yang memadai untuk melakukan tugas membimbing, membina, dan mengarahkan peserta didik dalam menumbuhkan semangat keunggulan, motivasi belajar, dan memiliki kepribadian serta budi pekerti luhur yang sesuai dengan budaya bangsa Indonesia. Selain itu, Kemendikbud (2013) juga menyatakan bahwa di dalam pembelajaran siswa didorong untuk menemukan sendiri dan mentransformasikan informasi kompleks, mengecek informasi baru dengan infromasi yang sudah ada dalam ingatannya. Hal ini dapat dikatakan bahwa guru dapat berperan sebagai fasilitator dalam keberlangsungan pembelajaran.

Pada abad 21 teknologi menjadi salah satu hal kunci dalam pelaksanaan berbagai kegiatan. Dampak dari kemajuan di abad 21 juga terjadi pada bidang Pendidikan salah satunya adalah pembelajaran yang berbasis teknologi. Kemajuan yang terjadi pada abad 21 menjadi tantangan tersendiri bagi guru sebagai pendidik terutama dalam melaksanakan pembelajaran dengan mengintegrasikan teknologi. Sebagai gambarannya, guru harus mampu mengenal teknologi, mengaplikasikan teknologi, dan mengembangkan produkproduk pembelajaran yang berintegrasi teknologi. Ketiga hal tersebut dapat menjadi salah satu kunci keberhasilan pembelajaran di abad 21. Guru abad 21 dituntut tidak hanya mampu mengajar dan mengelola kegiatan kelas dengan efektif, namun juga dituntut untuk mampu membangun hubungan yang efektif dengan siswa dan komunitas sekolah, menggunakan teknologi untuk mendukung peningkatan mutu pengajaran, serta melakukan refleksi dan perbaikan praktek pembelajarannya secara terus menerus (Darling, 2006). Pembelajaran pada abad 21 dapat diterapkan dalam kurikulum 2013 dengan melatih peserta didik untuk aktif dalam pembelajaran. Pembelajaran tematik yang dalam kurikulum 2013 dapat dikolaborasikan dengan student active learning (SAL) untuk memfasilitasi keaktifan peserta didik.

Student active learning memuat beberapa poin yang secara umum menekankan kepada proses keterlibatan siswa secara penuh untuk dapat menemukan materi yang dipelajari dan menghubungkannya dengan situasi kehidupan nyata sehingga mendorong siswa untuk dapat menerapkannya dalam kehidupan mereka. Pertama, active learning 
Kuncahyono, Dian. Pengembangan Pedoman E-Modul Berorientasi

menekankan kepada proses keterlibatan peserta didik untuk menemukan materi. Artinya proses belajar diorientasikan pada proses pengalaman secara langsung. Proses belajar dalam konteks active learning, tidak mengharapkan agar peserta didik hanya menerima pelajaran akan tetapi proses mencari dan menemukan sendiri materi pelajaran.

Kedua, active learning mendorong agar siswa dapat menemukan hubungan antara materi yang dipelajari dengan situasi kehidupan nyata, artinya peserta didik dituntut untuk dapat menangkap hubungan antara pengalaman belajar di sekolah dengan kehidupan nyata. Hal ini sangat penting, sebab dengan dapat mengkorelasikan materi yang ditemukan dengan kehidupan nyata, bukan saja bagi siswa materi itu akan bermakna secara fungsional akan tetapi materi yang dipelajarinya akan tertanam erat dalam memori peserta didik, sehingga tidak akan mudah dilupakan.

Ketiga, active learning mendorong siswa untuk dapat menerapkannya dalam kehidupan artinya active learning bukan hanya mengharapkan siswa dapat memahami materi yang dipelajarinya, akan tetapi bagaimana materi itu dapat mewarnai perilakunya dalam kehidupan sehari-hari. Materi pelajaran dalam konteks active learning bukan untuk ditumpuk di otak dan kemudian dilupakan, akan tetapi sebagai bekal mereka dalam mengarungi kehidupan nyata Sanjaya (2005:109-110).

Studi pendahuluan yang telah dilakukan peneliti bertujuan untuk mengungkap keberadaan sarana teknologi di SD Muhammadiyah 5 Malang. Diketahui bahwa keberadaan fasilitas teknologi dalam pembelajaran juga ditemui di SD Muhammadiyah 5 Malang yang memiliki laboratorium komputer lengkap dengan peralatan multimedia, ruang kelas yang dilengkapi dengan sarana LCD Proyektor, TV LED, seperangkat komputer personal, dan speaker aktif. Berdasarkan hasil observasi lapangan fasilitas teknologi perlu mendapat perhatian karena guru masih jarang menggunakan terutama dalam pembelajaran. Guru lebih dominan memanfaatkan buku guru maupun buku siswa yang sudah tersedia. Lebih dari $80 \%$ siswa masih menggunakan bahan ajar cetak (Byars, 2015). Adapun kelemahan segi biayanya bahan ajar cetak ini lebih mahal dibandingkan dengan bahan ajar elektronik. Hal ini tentunya diperlukan akomodasi agar siswa dapat belajar menggunakan bahan ajar berbasis computer sebagai mana Hasil penelitian yang dilakukan oleh (Rockinson dkk, 2012) menunjukan bahwa siswa yang menggunakan buku elektronik memiliki tingkat pembelajaran afektif dan psikomotor yang lebih tinggi. 
Kuncahyono, Dian. Pengembangan Pedoman E-Modul Berorientasi

Adanya kesenjangan kondisi nyata dengan kondisi ideal dalam pembelajaran tematik apabila tidak ditindaklanjuti, dikhawatirkan dapat mempengaruhi hasil belajar, motivasi, dan minat siswa. Melihat urgensi terhadap masalah dalam pembelajaran yang telah dipaparkan, maka hal tersebut sangat penting untuk dicarikan solusi pemecahan masalah yang terjadi pada pembelajaran tematik di SD Muhammadiyah 5 Malang. Salah satu alternatif untuk mengurangi pola pembelajaran teacher centered dan memaksimalkan sarana teknologi yang ada adalah mengembangkan bahan ajar atau media berbasis teknologi yang dapat memotivasi siswa dalam meningkatkan kualitas hasil belajar. Salah satu bahan ajar yang dapat mengatasi permasalahan tersebut adalah emodul. Melalui pemanfaatan pedoman e-modul guru dapat mengaktualisasikan kemampuan digital skills. Guru dapat mengimplementasikan produk e-modul (modul digital) yang telah dibuat pada tahap sebelumnya dan direalisasikan dalam kegiatan pembelajaran. Hasil riset (Kuncahyono \& Kumalasani, 2019) melalui penggunaan pedoman e-modul kompetensi digital skill guru mengalami peningkatan dari pretest 78 ke post test 84 . Dalam penggunaan e-modul diperlukan suatu pedoman yang dapat digunakan guru dalam memaanfaatkan e-modul yang dikembangkan. Keberadaan pedoman diharapkan akan mempermudah guru dalam menggunakan e-modul pada pelaksanaan pembelajaran tematik.

Berdasarkan kebutuhan lapang maka diperlukan bahan ajar berupa e-modul berbasis student active learning untuk Sekolah Dasar. Dalam implementasi penggunaan e-modul tidak terlepas dari beberapa kendala diantaranya guru cenderung mengalami kesulitan untuk memahami secara lisan langkah teknis penggunaan e-modul berbasis student active learning (Kuncahyono, 2018). Selain itu, penerapan e-modul berbasis student active learning cenderung mengalami kesulitan diterapkan pada Sekolah Dasar yang lain dikarenakan tidak adanya petunjuk teknis secara tertulis yang memuat langkahlangkah penggunaan e-modul berbasis student active learning.

Beberapa kendala yang dialami maka diperlukan pengembangan produk pedoman e-modul berorientasi student active learning sehingga memudahkan guru untuk memahami langkah-langkah teknis penggunaan e-modul berbasis student active learning. Setelah dilakukan pengembangan pedoman e-modul berorientasi student active learning juga akan dilakukan uji validitas dan uji coba kepada pengguna pedoman e-modul berbasis student active learning. Diharapkan dengan dikembangkannya pedoman e- 
Kuncahyono, Dian. Pengembangan Pedoman E-Modul Berorientasi

modul berorientasi student active learning juga lebih mudah diterapkan pada Sekolah Dasar yang lain karena guru dapat membaca secara langsung petunjuk teknis yang telah dituliskan dalam pedoman e-modul berorientasi student active learning.

\section{METODE PENELITIAN}

Penelitian pengembangan pedoman e-modul berbasis student active learning ini menggunakan model pengembangan ADDIE (Piskurich, 2000) dan (Branch, 2009) yang terdiri dari lima tahapan yaitu analisis (analysis), design (design), pengembangan (develop), implementasi (implementation), evaluasi (evaluate). Pada tahap analisis dilakukan pengumpulan data berupa observasi antara lain menyiapkan materi dan tempat penelitian. Materi disiapkan dalam bentuk petunjuk/pedoman e-modul. Lebih lanjut tempat penelitian dipilih dengan alasan sekolah tersebut belum memiliki pedoman emodul dalam pembelajarannya. Hasil analisis kebutuhan kemudian diolah untuk mengakomodasi berbagai keterbatasan yang ada di lapangan kemudian ditindaklanjuti dengan mendesain pengembangan media yang cocok dan belum pernah di terapkan dalam pembrlajaran.

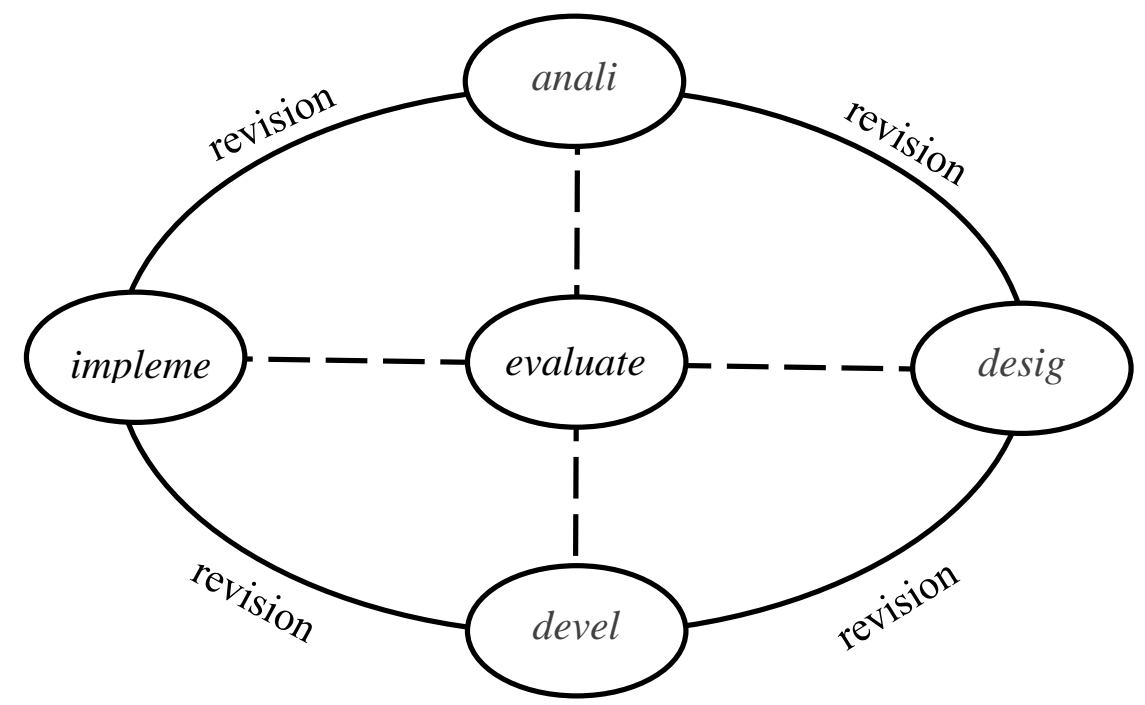

Gambar 1. Diagram model pengembangan ADDIE (Branch, 2009)

Pada tahap desain (design) dilakukan beberapa langkah yaitu (1) Menyiapkan materi pendukung dan menyusun materi sesuai dengan kebutuhan; (2) Menyusun tujuan pembelajaran; (3) Membuat draft prototype produk pedoman e-modul; (4) Pedoman yang didesain selain berisi petunjuk penggunaan e-modul juga berisi cara mengembangkan emodul menggunakan aplikasi/software. Luaran pada tahap ini adalah gambar dan teks 
Kuncahyono, Dian. Pengembangan Pedoman E-Modul Berorientasi

yang memuat langkah-langkah teknis penggunaan e-modul berbasis student active learning. Pedoman e-modul berbasis student active learning dirancang dengan ukuran

Tahap selanjutnya yaitu pengembangan (develop) yang dilakukan dengan proses membuat atau mengembangkan sumber belajar dan memvalidasinya. Pada tahap inilah yang merupakan tahap secara nyata dalam mengerjakan bahan ajar. Luaran pada tahap ini berupa pedoman e-modul berbasis student active learning yang layak secara teoretis. Tahap implementasi (implementation) dilakukan dengan melakukan ujicoba kelayakan di lapangan. Tahapan ujicoba digunakan untuk mengetahui, kelayakan dan kepraktisan pedoman e-modul berbasis student active learning. Ujicoba pengguna kepada guru dan peserta didik digunakan untuk mengetahui data kelayakan dan kepraktisan bahan ajar pedoman e-modul berbasis student active learning. Selain itu, pada tahap ini juga dilakukan validasi terhadap e-modul berbasis student active learning untuk mendapatkan masukan yang digunakan sebagai bahan pertimbangan untuk menyempurnakan produk yang telah dihasilkan.

Pada tahap evaluasi (evaluation) dilaksanakan untuk mengetahui hasil evaluasi secara kualitatif dan kuantitatif. Data kualitatif didapatkan dari angket validasi ahli, angket hasil uji coba ke peserta didik. Data Kuantitatif didapatkan dari hasil skor uji coba yang diperoleh. Adapun gambaran tahap evaluasi yaitu sebagai berikut: 1) Evaluasi uji coba produk, 2) analisis data deskriptif, 3) revisi produk akhir, dan 4) hasil akhir produk

\section{HASIL DAN PEMBAHASAN}

Produk yang dihasilkan dalam pengembangan ini yaitu berupa buku pedoman penggunaan dalam melaksanakan pembelajaran menggunakan e-modul. Buku pedoman yang dimaksud yaitu untuk memudahkan guru dan siswa menggunakan e-modul dalam pembelajaran tematik. Selanjutnya dengan dikembangkannya buku pedoman e-modul juga dapat membantu guru dalam memproduksi media berbasis teknologi yaitu modul digital sekaligus membantu guru dalam melaksanakan pembelajaran tematik dengan strategi pembelajaran student active learning. Sebagaimana pendapat Heinich (2002) bahwa modul ini disebut bahan ajaran kecil jikalau satuan kreditnya ditentukan Adapun spesifikasi produk pedoman e-modul terdiri atas a) halaman judul/Cover, b) Bagian I Pendahuluan: pada bagian ini berisi kata pengantar, daftar isi, daftar gambar, cakupan kompetensi, petunjuk penggunaan buku, petunjuk guru dan siswa, petunjuk tombol dan 
Kuncahyono, Dian. Pengembangan Pedoman E-Modul Berorientasi menu navigasi e-modul, c) Bagian II Isi : Pada bagian isi berisi instruksi penggunaan emodul oleh guru dan siswa serta cara membuatan/pengembangan e-modul oleh guru dengan menggunakan platform aplikasi yang sudah disediakan, dan d) bagian III Penutup: pada bagian penutup terdiri atas daftar rujukan, daftar buku, artikel, dokumen, dan berbagai sumber literatur yang dirujuk oleh penulis dalam menyusun pedoman e-modul.

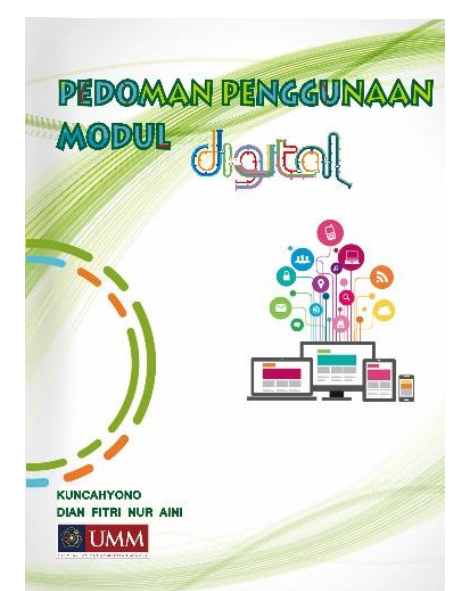

Gambar 2. Cover Pedoman e-Modul

Pada bagian 2 pedoman e-modul memuat pendahuluan: pada bagian pendahuluan ini berisi kata pengantar, daftar isi, daftar gambar, cakupan kompetensi, petunjuk penggunaan buku, petunjuk guru dan siswa, petunjuk tombol dan menu navigasi e-modul. Sebagaimana konsep modul menurut Association of Educational Communication and Technology (AECT) bahwa modul merupakan kumpulan bahan yang saling berkaitan yang dapat digunakan secara mandiri oleh siswa. Dapat dikatakan bahwa pentingnya modul bagi siswa sehingga siswa secara mandiri mampu belajar dan berlatih mengerjakan soal-soal yang ada di dalam modul.

Melalui pedoman ini dapat digunakan guru dan siswa sebagai pendukung pembelajaran tematik. Guru juga dapat mengikuti langkah-langkah penyusunan e-modul berorientasi student aktif learning. Lebih lanjut pada bagian dua pedoman e-modul terdapat petunjuk navigasi e-modul. Petunjuk navigasi modul berisi rincian tomboltombol yang dapat digunakan untuk mengoperasikan e-modul dengan mengintegrasikan secara offline maupun online menggunakan jaringan internet. Pemanfaatan jaringan computer digunakan sebagai daya dukung sumber belajar yang dapat dimasukkan ke dalam e-modul melalui link internet. 


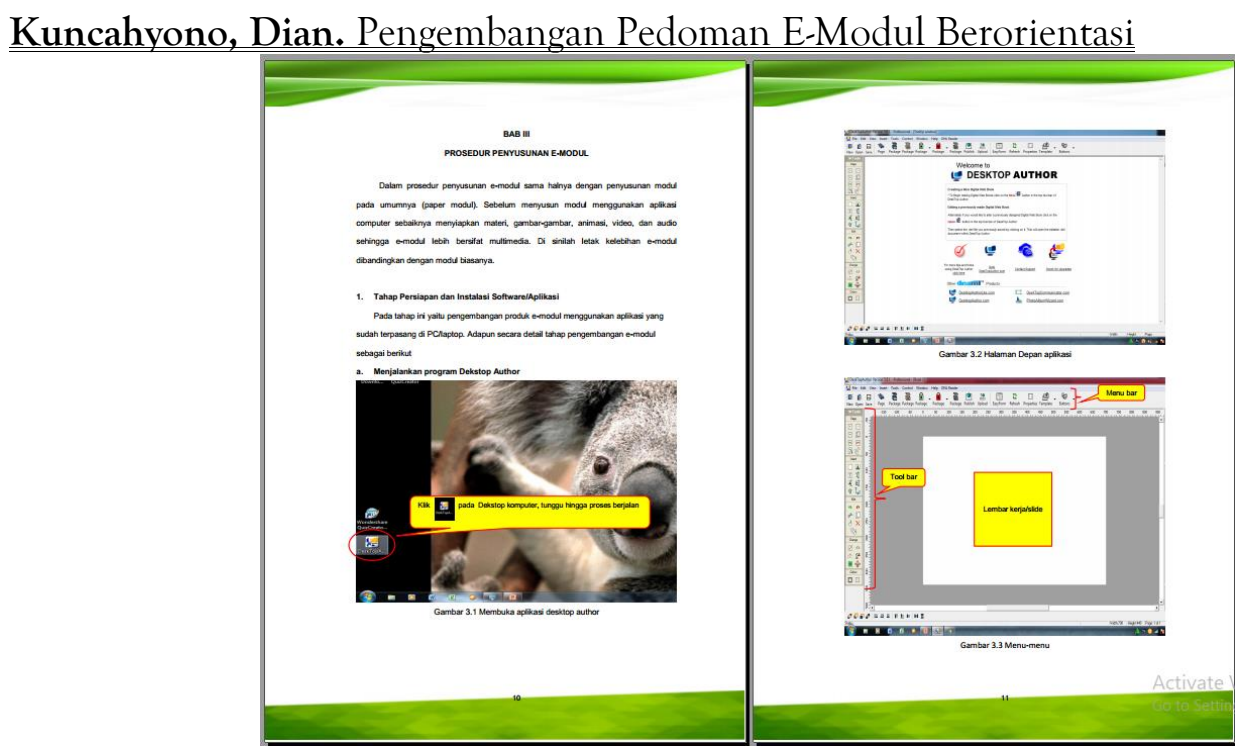

Gambar 3. Prosedur penyusunan e-modul

Berdasarkan gambar 3 pedoman e-modul berisi tentang prosedur atau langkah pembuatan e-modul berbasis computer. Pada bagian ini pedoman e-modul menyajikan secara lengkap melalui narasi yang disertai gambar/capture. Prosedur pembuatan dijabarkan secara jelas dan ringkas mulai dari tahap install software sampai dengan export hasil akhir. Guru dapat mengikuti prosedur secara bertahap agar tidak mengalami kesulitan.

Untuk mendapatkan produk pedoman yang layak maka diperlukan proses validasi sebelum dilakukan uji lapangan. Uji validasi dilakukan kepada validasi ahli meliputi validasi ahli bahan ajar dan ahli materi. Validasi ahli bahan ajar meliputi kelayakan tampilan interface pedoman e-mdoul, penggunaan huruf dan warna, penggunaan layout halaman sampul, dan kemenarikan desain. Selanjutnya, validasi materi meliputi materi tematik, student active learning, RPP, LKPD, dan validasi soal-soal latihan. Hasil dari validasi ahli bahan ajar mendapat skor 83,6 dengan kriteria baik dan valid. Hasil validasi ahli materi mendapat skor 84,3 dengan kriteria baik dan valid. Berdasarkan hasil kedua validator tampak bahwa pedoman e-modul mendapat kriteria layak. 
Kuncahyono, Dian. Pengembangan Pedoman E-Modul Berorientasi

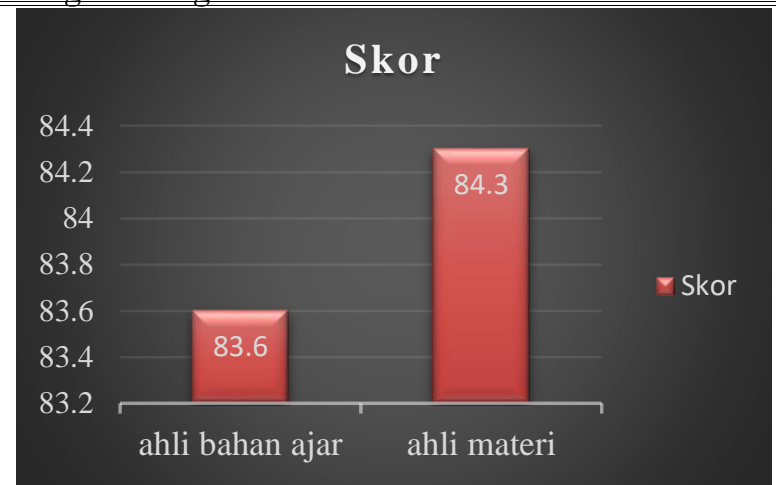

Gambar 4 Hasil Rekapitulasi validasi ahli

Selain kriteria tersebut terdapat saran dan evaluasi yang harus diperbaiki yaitu tata letak materi, keruntutan penomoran halaman, rubrik penilaian yang belum lengkap, dan kurangnya petunjuk penggunaan untuk guru maupun siswa. Berdasarkan hasil saran dan evaluasi tersebut kemudian direvisi terlebih dahulu sebelum diujicobakan di lapangan.

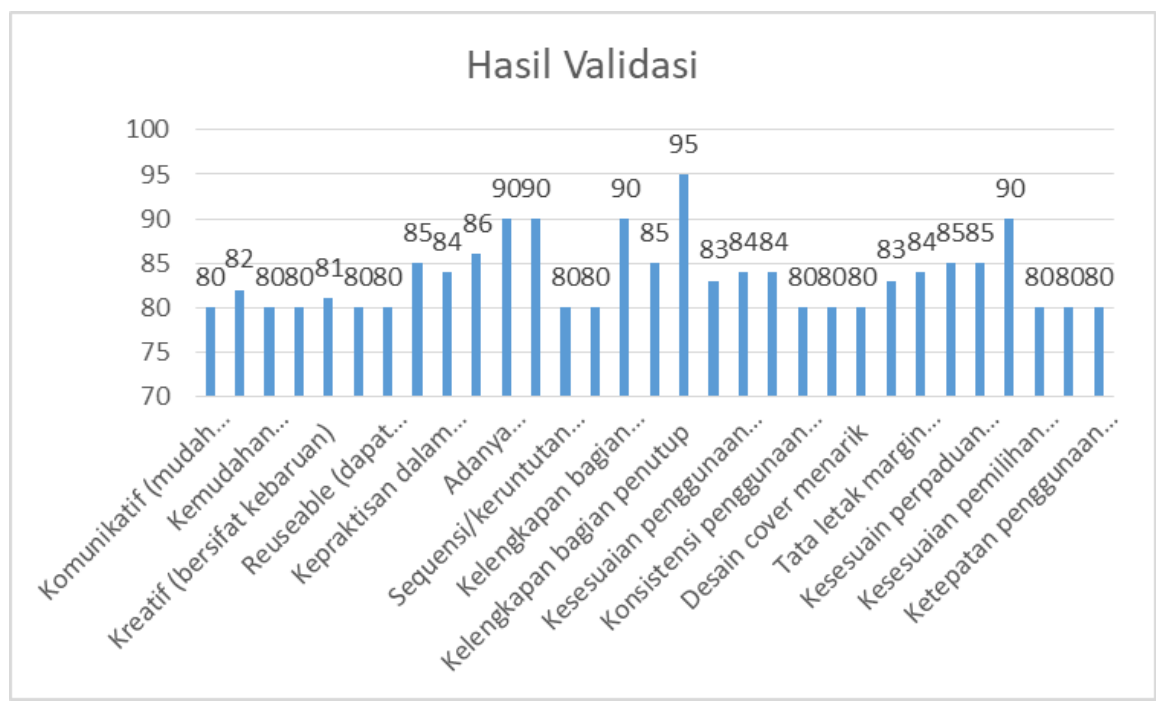

Gambar 5. Hasil Validasi

Berdasarkan gambar 5 dapat dideskripsikan bahwa hasil validasi ahli memperoleh persentase $83 \%$ dengan kriteria sangat valid. Adapun saran yang diberikan kepada validator yaitu, desain cover perlu dipertegas pada bagian judul, dan layout buku pedoman lebih dioptimalkan terutama tata letak interface. Berdasarkan hasil uji coba validasi ahli bahan ajar dan ahli materi maka rata-rata skor yang diperoleh yaitu 83,95 dengan kriteria valid.

\section{Respon Pengguna (siswa)}


Kuncahyono, Dian. Pengembangan Pedoman E-Modul Berorientasi

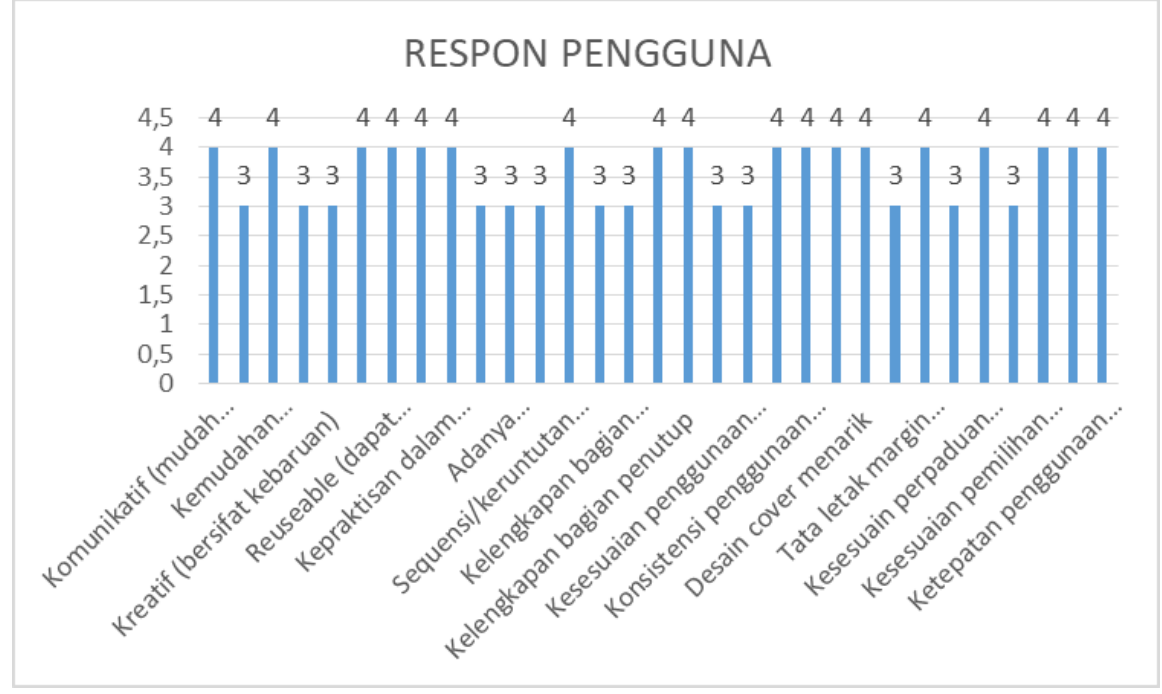

Gambar 6. Hasil respon pengguna

Berdasarkan gambar 6 dapat dideskripsikan bahwa hasil respon pengguna memperoleh skor total 111, dengan rata-rata skor 3,6 dengan kriteria sesuai. Saran yang dapat diberikan dari respon pengguna yaitu menambahkan petunjuk tambahan berupa tombol-tombol pada menu aplikasi agar lebih mudah dipahami. Lebih lanjut berikut paparan hasil respon pengguna terhadap pedoman e-modul dalam pembelajaran. Berdasarkan hasil olah data angket respon pengguna pada uji coba lapangan, pedoman emodul yang dikembangkan mendapat intepretasi menarik sebagai sumber bahan belajar dan layak digunakan. Pemilihan aplikasi pendukung berbasis komputer dalam pembuatan e-modul merupakan kontribusi perkembangan teknologi yang dapat dimanfaatkan dalam pembelajaran. Modul elektronik dapat digunakan sebagai bahan ajar alternatif berbasis teknologi karena mampu mengintegrasikan materi secara teks, gambar, animasi, audio, dan video interaktif. Hasil penelitian yang dilakukan oleh (Rockinson dkk, 2012) menunjukan bahwa siswa yang menggunakan buku elektronik memiliki tingkat pembelajaran afektif dan psikomotor yang lebih tinggi. Dapat disimpulkan bahwa hasil akhir pengembangan pedoman e-modul berorientasi student aktif learning ini layak digunakan sebagai bahan ajar alternatif pembelajaran tematik terpadu.

Hasil penelitian yang relevan terkait pengembangan modul interaktif menggunakan learning content development system (Kurniawan, 2014). Hasil penilitian menunjukkan bahwa uji coba eksternal dinilai menarik, mudah diaplikasikan, dan membawa kontribusi positif bagi pengguna (guru dan siswa) sebagai sumber belajar. Selanjutnya bedasarkan hasil penelitian (Handayani, 2016) menyatakan bahwa bahan ajar 
Kuncahyono, Dian. Pengembangan Pedoman E-Modul Berorientasi menggunakan mobile Learning mampu menyajikan kontribusi ilustasi media elektronik seperti laptop, smarphone, dan tablet sehingga lebih prkatis dibawa dan dipelajari kapanpun, dimanapun dan oleh siapapun. Perbedaan dengan hasil riset sebelumnya, peneliti disini selain menggunakan software/aplikasi berbasis komputer, peneliti juga mengkombinasikan dengan buku pedoman untuk memproduksi bahan ajar e-modul.

\section{Respon pengguna (Guru)}

Tabel 1. Rekapitulasi Hasil uji pengguna (Guru)

\begin{tabular}{|c|c|c|c|c|}
\hline No & Aspek & Indikator & Skor & Kategori \\
\hline \multirow[t]{5}{*}{1.} & \multirow{5}{*}{$\begin{array}{l}\text { Komunikasi } \\
\text { visual/interface }\end{array}$} & Komunikatif (mudah dipahami) & 4 & Sangat baik \\
\hline & & Kemudahan dalam pengoperasian & 3 & Baik \\
\hline & & $\begin{array}{ll}\begin{array}{l}\text { Kemudahan } \\
\text { pengoperasian }\end{array} & \text { tombol/petunjuk } \\
\end{array}$ & 3 & Baik \\
\hline & & Atraktif/bersifat menarik & 3 & Baik \\
\hline & & Kreatif (bersifat kebaruan) & 4 & Sangat baik \\
\hline \multirow[t]{5}{*}{2.} & \multirow[t]{5}{*}{ Kebermanfaatan } & Mudah digunakan (usabilitas) & 4 & Sangat baik \\
\hline & & Reuseable (dapat digunakan kembali) & 3 & Baik \\
\hline & & Keefektifan dalam penggunaan & 4 & \\
\hline & & Kepraktisan dalam penggunaan & 3 & Baik \\
\hline & & Petunjuk mudah dipahami & 3 & Baik \\
\hline \multirow[t]{4}{*}{3.} & \multirow{4}{*}{$\begin{array}{l}\text { Teknik } \\
\text { Penyajian }\end{array}$} & Adanya pengantar/Pendahulauan & 3 & Baik \\
\hline & & Konsistensi sistematika penyajian & 3 & Baik \\
\hline & & Sequensi/keruntutan penyajian & 4 & \\
\hline & & $\begin{array}{l}\text { Kemudahan penyajian petunjuk } \\
\text { penggunaan }\end{array}$ & 3 & Baik \\
\hline \multirow[t]{3}{*}{4.} & \multirow{3}{*}{$\begin{array}{l}\text { Kengkapan } \\
\text { penyajian }\end{array}$} & Kelengkapan bagian pendahuluan & 3 & Baik \\
\hline & & Kelengkapan bagian isi & 3 & Baik \\
\hline & & Kelengkapan bagian penutup & 4 & \\
\hline \multirow[t]{5}{*}{5.} & \multirow[t]{5}{*}{$\begin{array}{l}\text { Penyajian } \\
\text { Bahasa }\end{array}$} & $\begin{array}{l}\text { Keterbacaan kata/kalimat (readibility } \\
\text { tinggi) }\end{array}$ & 4 & Sangat baik \\
\hline & & $\begin{array}{l}\text { Kesesuaian penggunaan bahasa dengan } \\
\text { EYD }\end{array}$ & 4 & Sangat baik \\
\hline & & $\begin{array}{lll}\begin{array}{l}\text { Keefektifan } \\
\text { ambiguitas }\end{array} & \text { kalimat/Terhindar dari } \\
\end{array}$ & 3 & Baik \\
\hline & & Konsistensi penggunaan istilah & 4 & \\
\hline & & $\begin{array}{l}\text { Kesesuain bahasa dengan perkembangan } \\
\text { peserta didik }\end{array}$ & 3 & Baik \\
\hline \multirow[t]{11}{*}{6.} & \multirow[t]{9}{*}{ Desain/Layout } & Desain cover menarik & 4 & Sangat baik \\
\hline & & Ukuran buku proporsional & 3 & Baik \\
\hline & & Tata letak margin proporsional & 3 & Baik \\
\hline & & $\begin{array}{l}\text { Ketepatan penempatan Judul, subjudul, } \\
\text { ilustrasi, dan isi buku }\end{array}$ & 3 & Baik \\
\hline & & $\begin{array}{l}\text { Kesesuain perpaduan kontras warna } \\
\text { dengan latar belakang }\end{array}$ & 4 & Sangat baik \\
\hline & & Kesesuaian pemilihan jenis huruf & 4 & Sangat baik \\
\hline & & Kesesuaian pemilihan ukuran huruf & 3 & Baik \\
\hline & & Kesesuaian pemilihan warna huruf & 3 & Baik \\
\hline & & Ketepatan penggunaan spasi antar kalimat & 3 & Baik \\
\hline & Skor Total & & 105 & \\
\hline & Rata-rata skor & & 3,4 & Baik \\
\hline
\end{tabular}


Kuncahyono, Dian. Pengembangan Pedoman E-Modul Berorientasi

Hasil uji pengguna ini merupakan uji lapangan yang ditujukan kepada guru kelas V Sekolah dasar. Berdasarkan tabel 1 uji respon pengguna (guru) mendapat rata-rat skor 3,4 dengan kriteria baik. Terdapat saran-saran yang dapat digunakan sebagai bahan perbaikan dari pedoman e-modul yaitu masih terdapat penggunaan kalimat/ejaan yang salah, kurangnya tanda baca yang sesuai pada temapatnya, dan pedoman e-modul sudah mengakomodasi langkah-langkah pembuatan e-modul secara jelas. Berdasarkan hasil uji coba pengguna (guru dan siswa) maka rata-rata skor yang diperoleh yaitu 3,5 dengan sangat baik/sangat praktis.

\section{SIMPULAN}

Penelitian ini menggunakan desain penelitian pengembangan model ADDIE yang terdiri dari 5 tahapan yaitu analisis, perancangan, pengembangan, penerapan, dan evaluasi. Berdasarkan kajian teori dan penelitian yang relevan serta hasil uji coba pengguna (guru dan siswa) dapat disimpulkan bahwa pedoman e-modul berorientasi student aktif learning sangat menarik. Pedoman e-modul yang dihasilkan dapat dipahami oleh siswa dalam proses pembelajaran tematik. Hasil uji coba validasi ahli bahan ajar dan ahli materi maka rata-rata skor yang diperoleh yaitu 83,95 dengan kriteria valid. Hasil uji coba pengguna (guru dan siswa) maka rata-rata skor yang diperoleh yaitu 3,5 dengan sangat baik/sangat praktis.

\section{Saran Pemanfaatan}

Berdasarkan hasil produk pengembangan dan hasil uji coba pengguna, maka peneliti memberikan saran terkait pemanfaatan produk selanjutnya, meliputi:

a. Pedoman e-modul dapat digunakan secara maksimal untuk memproduksi e-modul sebagai aplikasi pembelaran berbasis online

b. Pemanfaatan pedoman e-modul hendaknya didukung oleh kajian terori dan sumbersumber yang relevan dengan materi

c. Pedoman e-modul dapat didesiminasikan melalui berbagai aspek materi, tampilan, desain lebih menarik, dan perpaduan strategi pembelajaran yang digunakan.

\section{DAFTAR PUSTAKA}

Branch, R. M. (2009). Instructional Design: The ADDIE Approach. Springer Science \& Business Media. 
Kuncahyono, Dian. Pengembangan Pedoman E-Modul Berorientasi

Byars, M.N. 2015. Printed Books versus Digital Books. California: the Faculty of the Graphic Communication Departement California Polytechnic State University

Deny Kurniawan, Agus Suyatna, W. S. 2014. Pengembangan Modul Interaktif Menggunakan Learning Content Development System pada Materi Listrik Dinamis. Jurnal Pembelajaran Fisika, 3(1), 1-10

Darling, Linda., H. 2006. Constructing 21st century teacher education. Journal of teacher education, 57. 300-314

Handayani, R.D. 2016. Pengembangan Bahan Ajar Elektronik Berbasis Mobile Learning pada Mata Kuliah Optik di FKIP Universitas Jember. Jurnal Ta'dib. Vol. 17, No. $1,81-85$

Heinich, R. et al. 2002. Instructional Media And Technology For Learning, 7th edition. New Jersey: Prentice Hall, Inc.

Kemdikbud. 2013. Peraturan MenteriPendidikan dan Kebudayaan Republik Indonesia No. 81 A Tahun 2013 Tentang Implementasi Kurikulum Pedoman Umum Pembelajaran.Jakarta:Kemendikbud

Kuncahyono, K. (2018). Pengembangan E-Modul (Modul Digital) dalam Pembelajaran Tematik Di Sekolah Dasar. JMIE (Journal of Madrasah Ibtidaiyah Education), 2(2), 219-231.

Kuncahyono, K., \& Kumalasani, M. P. (2019). Pengembangan Softskill Teknologi Pembelajaran Melalui Pembuatan E-Modul Bagi Guru Sekolah Dasar. TERAMPIL: Jurnal Pendidikan Dan Pembelajaran Dasar, 6(2), 128-139.

Mulyasa. 2007. Standar Kompetensi dan Sertifikasi Guru. Bandung: Remaja Rosdakarya. Piskurich, George M. 2000. The ASTD Handbook of Training Design and Delivery : A Comprehensive Guide to Creating and Delivering Training Programs, Instructorled, Computer-based, or Self-directed. United States: McGraw-Hill Professional Rockinson, A.J., Courduff, J., Carter, K. dan Bennett, D. 2013. Electronic versus Traditional Print Textbooks: A Comparison Study on the Influence of University Students Learning. Jour nal Hompage, 63 (2013) 259-266

Sanjaya, Wina. 2005. Pembelajaran dalam Implementasi Kurikulum Berbasis Kompetensi, Kencana Prenada. Jakarta: Media Grou 